DOI https://doi.org/10.30525/978-9934-588-91-4-2

\title{
СТРАХ СТАРОСТІ ТА ЕЙДЖИЗМ У КОНТЕКСТІ ПАНДЕМІЇ COVID-19: СОЦІАЛЬНО-ФІЛОСОФСЬКИЙ ТА СОЦІОКУЛЬТУРНИЙ АНАЛІЗ
}

\author{
Краснобока Т. В. \\ кандидат філософських наук, \\ доцент кафедри філософії, директор бібліотеки \\ Житомирського державного університету імені Івана Франка \\ м. Житомир, Украӥна
}

Зрозумілим стає, що світ на сьогодні зазнав значних трансформацій, можливість виникнення яких не передбачали навіть найдосвідченіші футурологи. Хтось називає пандемію COVID-19 помстою природи, інші - відпочинком природи, для когось - це знак людству, що потрібно зупинитися у своєму шаленому ритмі життя і почати жити більш розмірено у гармонії з собою та природою. Варіантів досить багато, але зрозумілим $\epsilon$ одне - світ став інший і перед людством постають нові виклики та нові проблеми, які претендують на рівень глобальних. Але ми хочемо звернути увагу на взаємовідносини людей у час масової загрози їх життю, зокрема на так зване «ранжування», кому жити, хто заслуговує на першочергову допомогу тощо.

Цікавим $є$ той факт, що людство ніби знову повертається у часи первісності у ставленні до людей похилого віку, їх знову готові «скинути» як не потрібний баласт. Варто зауважити, що це в першу чергу можна простежити у європейських країнах, у яких спостерігається в переважній більшості демографічне постаріння населення, але при цьому вони вважалися донедавна досить комфортними для життя людей похилого віку, зокрема, наприклад, Італія. Державою тут життя людини похилого віку було максимально захищеним, однак перед смертельною загрозою їх залишили безпорадними. Таким чином актуальним і досить гостро знову постає питання страху старості та проблеми ейджизму.

Зауважимо, що досліджуючи страх старості, нами у свій час було означене це поняття як внутрішній стан неспокою особистості, що виникає внаслідок виявлення й оцінки нею меж і агентів загрози існуванню, детермінованих реальними або майбутніми змінами, що безпосередньо чи опосередковано пов'язані з ії віком, основою виникнення якого $є$ уявлення про іiі майбутню соціальну і культурну дискримінацію [1, с. 4].

Щодо ейджизму, то даний термін, який означає дискримінацію за віковою ознакою загалом, ми в нашому дослідженні вживаємо як 
дискримінацію саме людей похилого віку за віковою ознакою. Введення поняття «ейджизм» (за аналогією 3 расизмом, шовінізмом), змістило проблему старіння з індивідуально-особистісного рівня на соціальний. Дане поняття належить Р. Батлеру, який дав наступне визначення ейджизму - це «...упереджене ставлення та дискримінація проти людей похилого віку [2, с. 425]».

Зазначимо, що ейджизм $є$ більше популістським поняттям, однак більш, зрозумілішим, ніж геронтофобія (що сприймається як специфічний патологічний страх або фобія перед старінням). Саме його введення допомогло привернути увагу до проблем дискримінації людей похилого віку.

У нашому дослідженні поняття «дискримінація» вживається у значенні обмеження у соціальних правах та позбавлення рівноправного становища групи населення, зокрема людей похилого віку.

Причинами дискримінації людей похилого віку, на наш погляд, $є$, в першу чергу, знецінення життя людини похилого віку, i, як наслідок, негативні стереотипи та упередженні чи безпідставні уявлення щодо них, перебільшення їх економічної залежності і фінансової неспроможності.

Дискримінаційний аспект прояву ейджизму породжує страх старості у такому його вияві, який можна означити як «страх соціального небуття» чи «страх соціального баласту». Можна стверджувати, що будь-які дискримінаційні прояви відносно людей похилого віку, відтак, тісно пов'язані із домінуючими культурними стереотипами спільноти про старість та негативізмом щодо людей похилого віку.

Таким чином, варто говорити про необхідність дослідження питання страху старості та проблеми ейджизму у контексті нових глобалізаційних викликів, зокрема пандемії COVID-19.

\section{Література:}

1. Коваль Т.В. Страх старості як чинник буття сучасної людини: автореф. дис. ... канд. філософ. наук : спец. 09.00.04 «Філософська антропологія, філософія культури»; Східноукраїнський нац. ун-т імені Володимира Даля. Луганськ, 2012. 18 с.

2. Schaefer R.T. Sociology: A Brief Introduction. 5-th ed. N.-Y.: McGraw-Hill Companies, Inc., 2004. XXXIII. 493 p. 